\title{
Suitability of Cut Corms as Planting Material on Flowering, Corm and Cormel Production in Gladiolus (Gladiolus grandiflorus L.) Varieties
}

\author{
Swapnil Bharti*, Urfi Fatmi and Devi Singh \\ Department of Horticulture, Naini Agricultural Institute, Sam Higginbottom University of \\ Agriculture, Technology and Sciences and Sciences, Allahabad-211007, U.P., India \\ *Corresponding author
}

\begin{tabular}{l} 
Ke y w o r d s \\
$\begin{array}{l}\text { Cut corms, Spike, } \\
\text { Florets, Daughter } \\
\text { corms, Cormels }\end{array}$ \\
Article Info \\
$\begin{array}{l}\text { Accepted: } \\
23 \text { June } 2017 \\
\text { Available Online: } \\
10 \text { August } 2017\end{array}$ \\
\hline
\end{tabular}

The present investigation entitled, "Suitability of Cut Corms as Planting Material on Flowering, Corm and Cormel Production in Gladiolus (Gladiolus grandiflorus L.) Varieties" was under taken in the Department of Horticulture, Naini Agricultural Institute, Sam Higginbottom University of Agriculture, Technology and Sciences, Allahabad during Rabi season (2016-2017). The experiment was layout in Factorial Randomized Block Design (FRBD) with 12 treatments and each treatment replicated thrice. The treatments consist of different division of corms (Full, Half and one- third) and 4 varieties (Deepest Red, Jessica, Amsterdam and Esta Bonita). Early spike emergence (55.27) was found when full corm was planted for Jessica Variety whereas spike length was maximum $(94.00 \mathrm{~cm})$ in variety Esta Bonita. Regarding number of florets per spike (14.83), number of daughter corms (65.16) per plant was found to be best in variety Amsterdam when full corms were planted whereas number of cormels (59.57) was found to be maximum in variety Deepest Red.

\section{Introduction}

Gladiolus is a popular flowering plant grown all over the world, from South Africa to West Asia. The term gladiolus was coined by Pliny the Elder (A.D-23-79) deriving from the Latin word "Gladius", because of its sword-like leaves. It is popularly known as sword lily. The modern hybrids are botanically known as Gladiolus grandiflorus belonging to family Iridaceae bearing chromosome number 60 . It is also known as "Queen of Bulbous Crops". Unlike other export oriented cut flower it can be raised under open field conditions and still produces exportable quality spikes. It is easy to grow and is commonly grown for garden use and for cut flower (Aswath and
Parathasarthy, 1996).In the international cutflower trade gladiolus occupies fourth place (Bhattacharjee and De, 2010).Gladiolus is grown commercially from corms both for the flowering spikes and for corm production and it is principally propagated by natural multiplication of new corms and cormels (Memon et al., 2009; Hartman et al., 1990; Ziv and Lilien-kipnis, 1990). However, owing to their low rate of multiplication and to a high percentage of spoilage of corms during storage, there is an insufficient supply of planting material (Memon et al., 2012; Singh and Dohare, 1994). In such a case, propagation may be done by cutting the corms 
into several pieces to increase the number of planting material. The segment of corm to be used as a propagule should have at least one eye and a portion of basal plate or root zone. Better results can be obtained when radial cuts are made the corms are cut 7 to 10 days before planting. Small corms can be divided into 3 to 4 pieces while the large one can be divided into 7 to 10 pieces (Gromov, 1972) which helps in providing benefits to the growers in increasing the planting materials.

\section{Materials and Methods}

\section{Experimental site and duration}

A field experiment entitled was conducted at Horticultural Experimental Field, Department of Horticulture, Sam Higginbottom University of Agriculture, Technology and Sciences, during Rabi season of 2016-17 from November to April.

\section{Experimental design}

$4 \times 3$ (4 varieties $\times 3$ corm sizes) factorial experiment was laid out in a Factorial Randomized Block Design with 3 replications.

\section{Treatments of the experiment}

Gladiolus variety $\left(\mathrm{V}_{1}\right.$ : Deepest Red; $\mathrm{V}_{2}$ : Jessica; $\mathrm{V}_{3}$ : Amsterdamand; V4: Esta Bonita) and corm sizes $\left(\mathrm{C}_{0}\right.$ : whole corm; $\mathrm{C}_{1}$ : Half size corm; $\mathrm{C}_{2}$ : one-third corm were used in the experiment.

\section{Plot size}

The size of unit plot was $2 \mathrm{~m} \times 2 \mathrm{~m}$.

\section{Procedure for the application of treatments}

Few corms were cut into two sections and few into three sections retaining abud with each section. Bavastin was applied to the segments and whole corm to prevent fungus. Then the segments and whole corms are treated with GA3 to break dormancy.

\section{Planting of the corms}

Corms were planted at $5 \mathrm{~cm}$ depth in the plot maintaining $30 \mathrm{~cm}$ x $20 \mathrm{~cm}$ spacing. In each plot, 20 corms were planted.

\section{The different treatment combinations are as follows}

$\mathrm{T}_{1}\left(\mathrm{~V}_{1} \mathrm{C}_{0}\right)$ Deepest Red x Full size corm; $\mathrm{T}_{2}$ $\left(\mathrm{V}_{1} \mathrm{C}_{1}\right)$ Deepest Red $\mathrm{x}$ Half size corm; $\mathrm{T}_{3}$ $\left(\mathrm{V}_{1} \mathrm{C}_{2}\right)$ Deepest Red x One-third corm size; $\mathrm{T}_{4}$ $\left(\mathrm{V}_{2} \mathrm{C}_{0}\right)$ Jessica $\mathrm{x}$ Full size corm; $\mathrm{T}_{5}\left(\mathrm{~V}_{2} \mathrm{C}_{1}\right)$ Jessica $\mathrm{x}$ Half size corm; $\mathrm{T}_{6}\left(\mathrm{~V}_{2} \mathrm{C}_{2}\right)$ Jessica $\mathrm{x}$ One-third corm size; $\mathrm{T}_{7}\left(\mathrm{~V}_{3} \mathrm{C}_{0}\right)$ Amsterdam $\mathrm{x}$ Full size corm, $\mathrm{T}_{8}\left(\mathrm{~V}_{3} \mathrm{C}_{1}\right)$; Amsterdam $\mathrm{x}$ Half size corm; $\mathrm{T}_{9}\left(\mathrm{~V}_{3} \mathrm{C}_{2}\right)$ Amsterdam $\mathrm{x}$ One-third corm size; $\mathrm{T}_{10}\left(\mathrm{~V}_{4} \mathrm{C}_{0}\right)$ Esta Bonita $\mathrm{x}$ Full size corm; $\mathrm{T}_{11}\left(\mathrm{~V}_{4} \mathrm{C}_{1}\right)$ Esta Bonita $\mathrm{x}$ Half size corm; $\mathrm{T}_{12}\left(\mathrm{~V}_{4} \mathrm{C}_{2}\right)$ Esat Bonita $\mathrm{x}$ One-third corm size

\section{Results and Discussion}

\section{Floral parameters}

\section{Number of days taken for spike emergence}

Interaction effect revealed that minimum number of days taken for spike emergence (55.27) was recorded in $T_{4}$ followed by $T_{1}$ (72.33) whereas maximum number of days was in $\mathrm{T}_{12}(100.43)$.

Large size corm helps the plant for growth and development with supplying storage nutrients in the corm which is the ultimate result of minimum days for emergence of spike. Similar findings were also found by Bhat et al., (2009) in gladiolus. 


\section{Spike length (cm)}

Interaction effect revealed that maximum spike length $(94.00 \mathrm{~cm})$ was recorded in $\mathrm{T}_{10}$ followed by $\mathrm{T}_{7}(83.40 \mathrm{~cm})$. The spike length was found to be minimum in $\mathrm{T}_{6}$ is $41.91 \mathrm{~cm}$. This might be due to the higher amount of stored food material from large corm which resulted in larger spike length. Similar results were also reported by Dod et al., (1989) and Bhattacharjee (1981) (Table 1).

\section{Number of florets per spike}

Interaction effect revealed that maximum number of florets per spike (14.83) was recorded in $\mathrm{T}_{7}$ followed by $\mathrm{T}_{10}$ (12.63) whereas minimum in $\mathrm{T}_{6}$ (7.63). Plant height and spike length had direct influence on number of florets per spike and improvement in spike length and plant height directly increased number of florets per spike. Similar findings were given by Mahesh et al., 2011 (Table 2).

\section{Diameter of basal floret (mm)}

Interaction effect revealed that maximum diameter of basal floret $(125.42 \mathrm{~mm})$ was recorded in $\mathrm{T}_{10}$ followed by $\mathrm{T}_{7}(112.62 \mathrm{~mm})$. The diameter of minimum in $\mathrm{T}_{6}$ is $67.74 \mathrm{~mm}$. Diameter of florets indicating that with the increment of plant height this associated character could be improved (Kumar et al., 2011).

Table.1 Effect of cut corms on floral parameters on different gladiolus (Gladiolus grandiflorus L.) Varieties

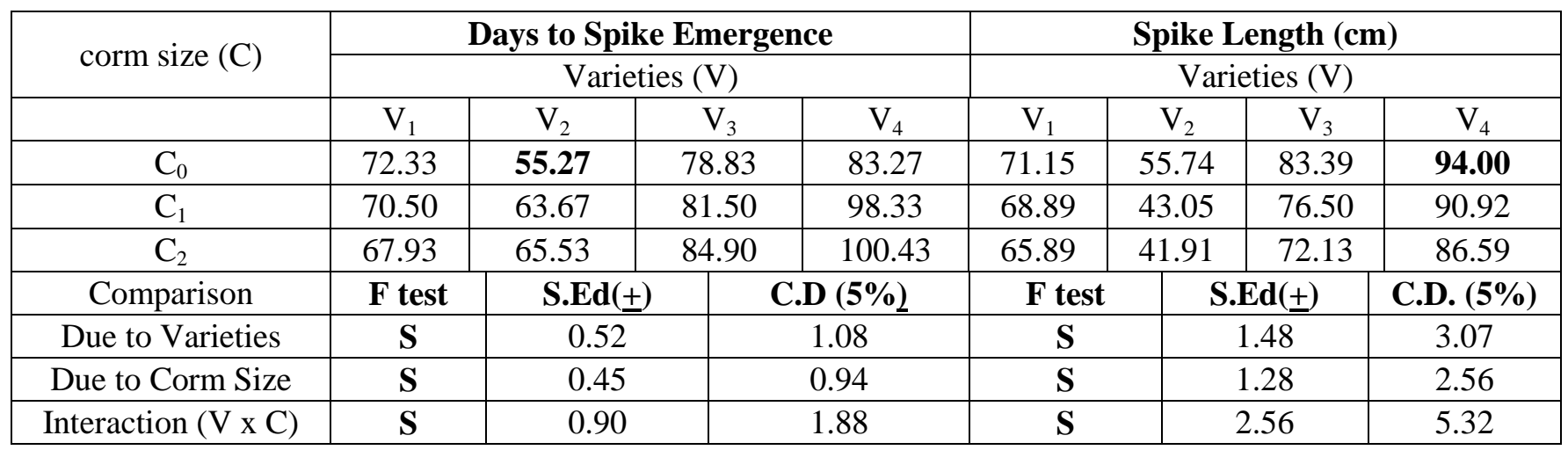

Table.2 Effect of cut corms on floral parameters on different gladiolus (Gladiolus grandiflorus L.) varieties

\begin{tabular}{|c|c|c|c|c|c|c|c|c|}
\hline \multirow{3}{*}{ corm size $(\mathrm{C})$} & \multicolumn{4}{|c|}{ No of florets per spike } & \multicolumn{4}{|c|}{ Diameter of basal floret(mm) } \\
\hline & \multicolumn{4}{|c|}{ Varieties (V) } & \multicolumn{4}{|c|}{ Varieties (V) } \\
\hline & $\mathrm{V}_{1}$ & $\mathrm{~V}_{2}$ & $\mathrm{~V}_{3}$ & $\mathrm{~V}_{4}$ & $\mathrm{~V}_{1}$ & $\mathrm{~V}_{2}$ & $\mathrm{~V}_{3}$ & $\mathrm{~V}_{4}$ \\
\hline $\mathrm{C}_{0}$ & 12.27 & 10.93 & 14.83 & 12.63 & 88.21 & 76.73 & 112.62 & 125.42 \\
\hline $\mathrm{C}_{1}$ & 11.83 & 9.28 & 14.47 & 11.93 & 82.34 & 71.64 & 108.10 & 122.55 \\
\hline $\mathrm{C}_{2}$ & 10.87 & 7.63 & 13.73 & 11.20 & 78.16 & 67.74 & 105.53 & 119.00 \\
\hline Comparison & F test & \multicolumn{2}{|c|}{$\operatorname{S.Ed}( \pm)$} & C.D (5\%) & \multicolumn{2}{|c|}{ F test } & S.Ed( $( \pm)$ & C.D. (5\%) \\
\hline Due to Varieties & $\mathbf{S}$ & \multicolumn{2}{|c|}{0.27} & 0.58 & \multicolumn{2}{|c|}{$\mathbf{S}$} & 0.71 & 1.49 \\
\hline Due to Corm Size & $\mathbf{S}$ & \multicolumn{2}{|c|}{0.24} & 0.50 & \multicolumn{2}{|c|}{$\mathbf{S}$} & 0.62 & 1.29 \\
\hline Interaction $(\mathrm{V} \times \mathrm{C})$ & $\mathbf{S}$ & \multicolumn{2}{|c|}{0.48} & 1.00 & \multicolumn{2}{|c|}{$\mathbf{S}$} & 1.24 & 2.58 \\
\hline
\end{tabular}


Table.3 Effect of cut corms on yield parameters on different gladiolus (Gladiolus grandiflorus L.) varieties

\begin{tabular}{|c|c|c|c|c|c|c|c|c|}
\hline \multirow{3}{*}{ Corm size $(\mathrm{C})$} & \multicolumn{4}{|c|}{ Weight of daughter corms per plant (g) } & \multicolumn{4}{|c|}{ Number of cormels per plant } \\
\hline & \multicolumn{4}{|c|}{ Varieties (V) } & \multicolumn{4}{|c|}{ Varieties (V) } \\
\hline & $\mathrm{V}_{1}$ & $\mathrm{~V}_{2}$ & $\mathrm{~V}_{3}$ & $\mathrm{~V}_{4}$ & $\mathrm{~V}_{1}$ & $\mathrm{~V}_{2}$ & $\mathrm{~V}_{3}$ & $\mathrm{~V}_{4}$ \\
\hline$\overline{\mathrm{C}_{0}}$ & 24.77 & 28.82 & 52.85 & 48.43 & 59.57 & 18.07 & 41.73 & 33.80 \\
\hline $\mathrm{C}_{1}$ & 24.43 & 22.37 & 43.50 & 45.90 & 39.33 & 16.50 & 28.30 & 28.63 \\
\hline $\mathrm{C}_{2}$ & 20.93 & 18.93 & 40.17 & 41.20 & 36.87 & 8.63 & 24.83 & 20.40 \\
\hline Comparison & F test & \multicolumn{2}{|c|}{ S.Ed( $( \pm)$} & C.D (5\%) & F test & \multicolumn{2}{|c|}{ S.Ed( $(+)$} & C.D. $(5 \%)$ \\
\hline Due to Varieties & $\mathbf{S}$ & 0.48 & & 0.98 & $\mathbf{S}$ & \multicolumn{2}{|c|}{0.43} & 0.89 \\
\hline Due to Corm Size & $\mathbf{S}$ & \multicolumn{2}{|c|}{0.41} & 0.86 & $\mathbf{S}$ & \multicolumn{2}{|c|}{0.37} & 0.77 \\
\hline Interaction $(\mathrm{V} \times \mathrm{C})$ & $\mathbf{S}$ & 0.83 & \multicolumn{2}{|c|}{1.71} & $\mathbf{S}$ & \multicolumn{2}{|c|}{0.75} & 1.55 \\
\hline
\end{tabular}

\section{Yield parameters}

\section{Weight of daughter corms (g)}

Interaction effect revealed that maximum weight of daughter corms $(52.85 \mathrm{~g})$ was recorded in $\mathrm{T}_{7}$ followed by $\mathrm{T}_{10}(48.43 \mathrm{~g})$ whereas minimum in $\mathrm{T}_{6}(18.93)$.This may be attributed to the good vegetative growth of plants in initial stages, which provides good amount of photosynthates for storage in corms. It may be mentioned here that when the half corm or whole corm were planted, the innermost corms developed on the terminal bud were larger and heavier than the outer corms which were smaller and lighter, implying that the available food materials were first translocated to the central corms and thereafter to the laterals. Similar results were given by Mahasen et al., 2015 (Table 3)

\section{Number of cormels per plant}

Interaction effect revealed that maximum number of cormel formed per plant (59.57) was recorded in $T_{1}$ followed by $T_{7}$ (41.73) whereas minimum in $\mathrm{T}_{6}(8.63)$. The result is in an agreement with the findings of Joshi $e t$ al., (2011)

On the basis of present investigation early spike emergence was found in $V_{2}$ (Jessica) whereas spike length was best in $\mathrm{V}_{4}$ (Esta
Bonita) followed by $\mathrm{V}_{\mathbf{3}}$ (Amsterdam). Regarding number of florets per spike, no. of daughter corms per plant was found to be best in $V_{3}$ (Amsterdam). Full corms were found to be best in terms of all vegetative and floral parameters but in terms of corms and cormel production cut corms were found to be better. So cut corm can be used for commercial gladiolus production and this might reduce the cost for planting materials.

\section{Acknowledgement}

We authors are greatly thankful to other professors and members, Department of Horticulture, Naini Agricultural Institute, for their guidance and support during the research trail and also thankful to Department of Soil Science and Department of Agro- metrology for their information.

\section{References}

Aswath, C., and Parathasarathy, V.A. 1996. Evaluation of gladiolus cultivars. J. Hill Res.9 (I):147-149

Bhat, Z. A., Paul, T. M., Mir, M. M. 2009. Effect of corm size and planting geometry on growth, flowering and corm production in gladiolus cv. White Prosperity. J. Orn. Hort. 12(1): 35-38.

Bhattacharjee, S. K., 1981. Flowering and corm production of gladiolus as 
influenced by corm size, planting depth and spacing. Singapore J. Prim. Ind. 9(1):18-22.

Bhattacharjee, S. K., and De, L. C. 2010. Gladiolus Advanced Commercial Floriculture. Rev. Edn. Aavishkar Publ. Jodhpur, India 1: 309-310

Gromov, A. N., 1972. The world of the gladiolus. NAGC, USA, 98-102.

Joshi, K. R., Gautam, D. M., Baral, D. R., and Pun, U. K. 2012. Effect of corm size and varieties on corm/cormels production and vase life of gladiolus.Nepal J. Sci. and Tech., 12: 35-40.

Kumar, J., Kumar, R., Pal and Krishan. 2011. Variability and character association in gladiolus (Gladiolus grandiflorusL.).Agricultural Science Digest 31(4):30

Mahasena, M., Onaa, A. F., Taufiquea, T., Mehrajb, H., and Uddina, A. J. 2015. Suitability of cut corm as planting materials on flowering and corm-cormel production of gladiolus cultivars. $J$. Bioscience and Agri. Res. 4(01), 10-19.

Rashmi, L., 2006. Evaluation of promising hybrids of gladiolus.M.Sc. (Agri.) Thesis, University of Agricultural Sciences, Dharwad, India.

Mahesh, C., Moond, S. K. and AnopKumari. 2011. Correlation studies in gladiolus. Research in Plant Biology 1(4): 68-72.

Memon, N., Qasim, M., Jaskani, M. J., Awan, F. S., Iqbal, A., Khan, I., Sadia, B. and
Hussain, Z. 2012. Assessment of soma clonal variation in in vitro propagated cormels of gladiolus. Pak. J. Bot. 44(2): 769-776.

Memon, N., Qasim, M., Jaskani, M. J., Rashid, A. and Iftikhar, A. 2009. Enhancement of corm and cormel production in gladiolus (Gladiolus spp.)New Zealand J. Crop and Horti. Sci. 37: 319-325.

Hartmann, H. T., Kester, D. E., Davies, F. T., and Geneve, R. L. 1997. Plant propagation: principles and practices (No. Ed.6). Prentice-Hall Inc.

Dod, V. N., Sadavarke, K. T., Kulwal, L. V. and Vaidya, S. W. 1989. Effect of different dates of planting and size of corm on growth, flowering and yield of gladiolus.

Punjab

RaoKrishiVidyapeethRes.J.13 (12): 164-165

Singh, A. P., and Dohare, S. R. 1994. Maximization of corms and cormel production in Gladiolus. In: Prakash, J. and K. R. Bhandary ed., Floriculture Technology, trades and trends. Oxford \& IBH Pub. Co. Pvt. Ltd. India.205208.

Ziy, M., and Lilien-Kipnis, H. 1990. Gladiolus. In: Ammirato, P. A., Evans, D. A. Shark, W. R. and Bajaj Y. P. S. ed. Handbook of plant cell culture. McGrawhill Publishing Company, New York. 461-478.

\section{How to cite this article:}

Swapnil Bharti, Urfi Fatmi and Devi Singh. 2017. Suitability of Cut Corms as Planting Material on Flowering, Corm and Cormel Production in Gladiolus (Gladiolus grandiflorus L.) Varieties. Int.J.Curr.Microbiol.App.Sci. 6(8): 2935-2939. doi: https://doi.org/10.20546/ijcmas.2017.608.352 